\title{
Full mouth rehabilitation of edentulous patient with fixed implant prosthesis
}

\author{
Hee-Hyun Shin', Jong-Jin Kim', Jin Baik', Hyun-Suk Cha², Joo-Hee Lee ${ }^{2 *}$ \\ 'Divison of Prosthodontics, Department of Dentistry, Asan Medical Center, Seoul, Republic of Korea \\ 'Divison of Prosthodontics, Department of Dentistry, Asan Medical Center, College of Medicine, University of Ulsan, Seoul, \\ Republic of Korea
}

There are various treatment options such as conventional complete denture, hybrid prosthesis and implant-supported fixed prosthesis for fully edentulous patients. In case of implant-supported fixed prosthesis, compared to removable prosthesis, it is difficult to place the implant in the correct position considering the anatomical contours of the final prosthesis. In this case, a full mouth rehabilitation with implant-supported fixed prosthesis was performed for a patient who required extraction of all remaining teeth due to dental caries and chronic periodontitis. In the implant placement stage, the implant was placed in the desired position using a surgical guide fabricated considering the anatomical contours of the final prosthesis, and the function and esthetics were evaluated through correction and re-fabrication of the fixed provisional restoration. A final restoration of porcelain fused to gold prosthesis was delivered to the patient based on the provisional restoration. To cope with complications such as loosening of screws and fracture of porcelain, a screw-retained type prosthesis was fabricated for the posterior part and a screw-cement-retained type prosthesis for the anterior part. As a result, the patient showed an improved prognosis in terms of functional and esthetics after the final prosthesis was delivered. (J Dent Rehabil Appl Sci 2021;37(3):147-56)

Key words: fully edentulous patient; implant-supported fixed prosthesis; implant surgical stent

\begin{abstract}
서론
무치악 환자의 구강 회복은 통상적인 총의치, 임플란 트 피개의치, 하이브리드 보철물, 임플란트 고정성 수복 물 등 다양한 치료 옵션을 통해 이루어질 수 있다. 치과의 사는 환자의 심미적 요구 및 환자의 술 전 상태, 사회경제 적 상황 및 구강 위생 관리 능력 등을 고려하여 여러 가지 치료 옵션 중 최적의 치료 계획을 선택하여야 한다. ${ }^{1}$ 임플 란트 고정성 수복물을 통한 보철 치료 시 환자의 골의 양 과 질, 입술 선, 구순 지지 등을 평가하여 계획된 위치에 임플란트를 정확하게 식립하는 것이 중요하다. ${ }^{1}$
\end{abstract}

*Correspondence to: Joo-Hee Lee

Professor, Division of Prosthodontics, Department of Dentistry, Asan Medical Center, College of Medicine, University of Ulsan, 88 Olympic-ro 43-gil, Songpagu, Seoul, 05505, Republic of Korea

Tel: +82-2-3010-3850, Fax: +82-2-3010-6967, E-mail: ljhl11911@hanmail.net

Received: July 23, 2021/Last Revision: August 3, 2021/Accepted: August 25, 2021
갑상선 기능 이상은 내분비계 질환 중 두 번째로 흔한 질환으로 이중 갑상선 중독증은 갑상선 호르몬의 조절되 지 않는 생성으로 발생하며 진전, 감정적 불안정, 동성 빈 맥, 수축기 심잡음, 고혈압 등을 특징으로 한다. ${ }^{2}$ 갑상선 중독증을 가진 환자는 갑상선 호르몬의 교감신경계 활성 에 대한 영향으로 혈압과 심박수가 증가 되어있을 수 있 다. ${ }^{2}$ 갑상선 중독증에 수반되어 나타날 수 있는 고혈압을 예방하기 위해 갑상선 중독증 환자들은 아스피린 및 b차단제 등을 복용하고 있을 가능성이 크다. ${ }^{2}$ 또한 와파 린을 복용중인 갑상선 중독증 환자는 와파린 대사가 증 가되어 혈액 응고 인자 관련 수치가 조절되지 않을 수 있

Copyright (C) 2021 The Korean Academy of Stomatognathic Function and Occlusion. (c) It is identical to Creative Commons Non-Commercial License. 
다. ${ }^{2}$ 갑상선 기능 억제제의 경우 혈액 응고에 관여하는 비 타민 $\mathrm{K}$ 활성을 억제하여 출혈 위험성을 증가시킬 수 있 으므로 관혈적 치과 시술 전 내과 전문의와의 상담을 통 한 출혈 관련 약물의 조절이 필요할 것이다. ${ }^{2}$

갑상선 중독증의 구내 합병증으로는 치아 우식과 치주 염 감수성의 증가, 악골의 골다공증, 맹출 속도의 증가, 구강 작열감 증후군 등이 있다. ${ }^{2}$ 구강 작열감 증후군은 구강 건조증을 유발하며 갑상선 질환을 가진 환자들에게 서 흔히 나타난다. ${ }^{2}$

본 증례에서는 만성 치주염과 치아우식에 의해 기능과 심미가 무너져 전악 발거가 요구되는 갑상선 중독증 환 자의 완전 구강 회복을 전악 임플란트 고정성 수복물을 통해 진행하였다. 임플란트 식립 전 수술용 가이드를 제 작하였고 이를 이용하여 조직 유도 골 재생술을 동반한 상, 하악 다수의 임플란트 식립 시행하였다. 이후 금속 도 재관으로 최종 수복 진행하였으며 환자와 술자 모두 기 능과 심미 측면에서 만족할 만한 결과를 얻어 이에 대해 보고하고자 한다.

\section{증례 보고}

본 증례의 50 세 여성 환자는 임플란트 고정성 수복물 로 보철치료를 받고 싶다는 것을 주소로 초진 내원하였 다. 환자는 갑상선 중독증을 않고 있었으며 모든 치열에 서 치석 침착 관찰할 수 있었고 치아 우식에 의한 치관 파 절이 일어나 상악 우측 제 1 소구치 및 제 1 대구치, 하악 좌. 우측 제 2 소구치가 잔존 치근 상태였다. 이에 따라 하악 우측 제 1,2 대구치 및 상악 좌측 제 1,2 대구치의 과정출 이 일어나 교합 수직 고경 상실이 발생했으며, 하악 좌측 제 1,2 대구치 및 상악 우측 제 2 소구치와 제 2 대구치는 결 손 상태였다. 이 외의 잔존치에서 심한 치아우식을 보여 모든 잔존 치아의 발거를 필요로 하였다(Fig. 1A-H).

환자는 본원 내원 3 년 전 갑상선 중독증을 진단받았으 며 갑상선 중독증 증상 중 구강건조증을 호소하였다. 이 로 인해 타액에 의한 자정작용이 감소하였으며, 경제적 사정에 의해 치과 치료 및 관리가 부족하여 젊은 나이임 에도 불구하고 심한 치아우식 및 만성 치주염 증상을 보
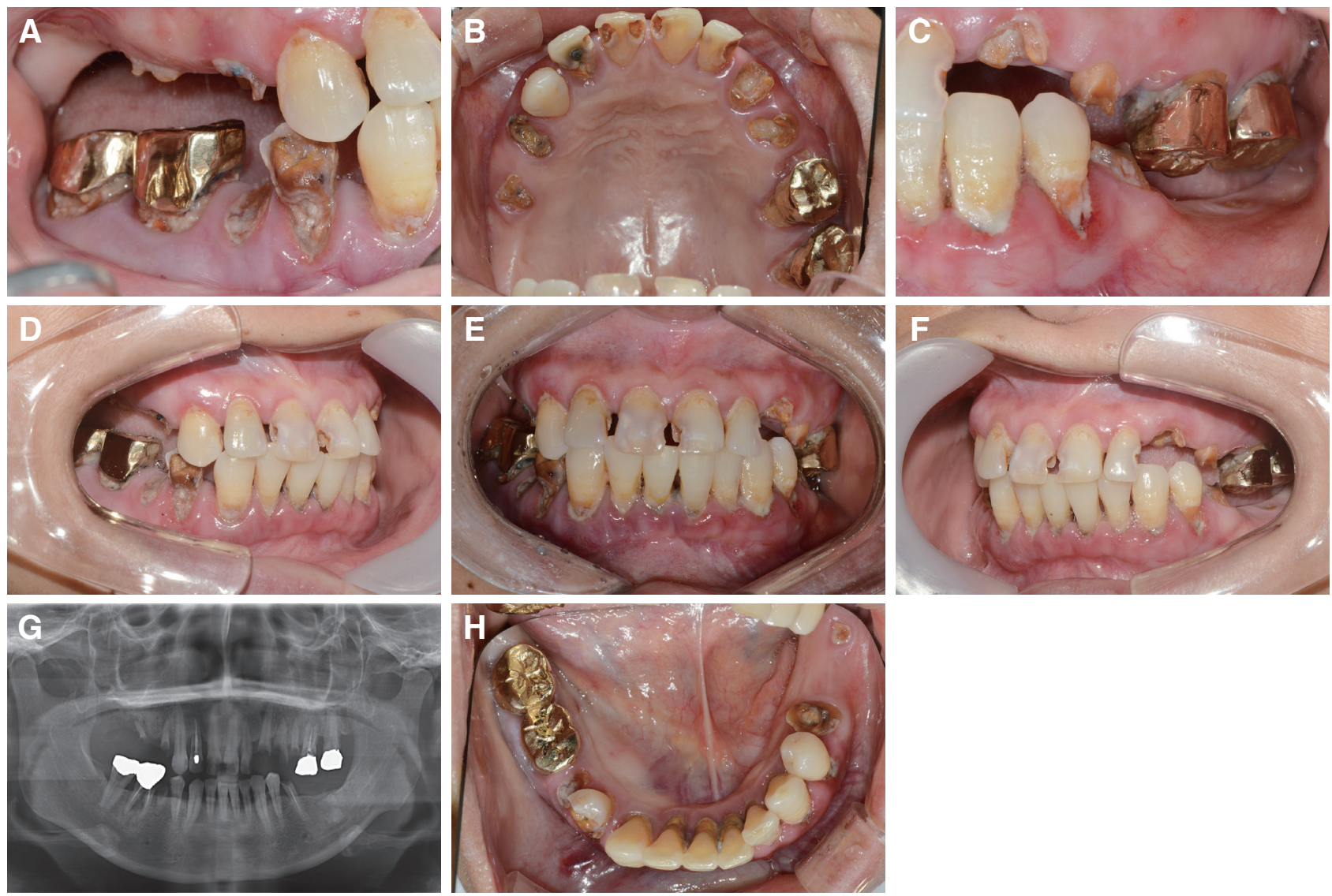

Fig. 1. Pre-operative intraoral photographs $(A-F, H)$, radiographic evaluation $(G)$ : severe dental caries and loss of vertical dimension were detected. (A, D) Lateral view (right side), (B) Occlusal view of maxilla, (C, F) Lateral view (left side), (E) Frontal view, $(G)$ panoramic radiograph, $(H)$ Occlusal view of mandible. 
여 전악 발거 후 임플란트 지지 고정성 수복물로 완전 구 강 회복 계획하였다.

환자의 갑상선 중독증은 잘 조절되고 있었으며 이와 관련하여 출혈 위험성을 증가시키는 아스피린과 기넥신 을 복용 중이었다. 혈액 검사 결과 국제 표준화 수치(International Normalized ratio, INR) 정상이었으며 내과 주치의와 상의하여 발치 7일 전부터 위 약물의 복용을 중 단하였다. 총 3 회에 걸쳐 잔존 자연치아 모두 발치 후 상, 하악 임시 총의치 장착하였다.

발치 후 구순 지지를 평가하기 위해 진단 모형 제작 후 교합제 상에 인공치아를 배열한 후 환자에게 시적 해 보 았다. 그 결과 중등도의 구순 지지 소실로 평가되어 환자 에게 임플란트 지지 고정성 보철물로 구순 지지의 회복 이 가능하며 이를 임시 보철물로 평가해볼 수 있음을 설 명하였고 최종적으로 임플란트 지지 고정성 보철물로 수 복 진행하기로 하였다.

발치 4개월 후 무치악 치조제의 알지네이트 인상 채득 후 기록상과 교합제로 구순 지지 및 수직 교합 고경 결정 하고 최종 보철물 형태 반영하여 인공 치아 배열 진행하 였다(Fig. 2A-B). 환자에게 배열된 치아 시적 후 이를 이 용하여 레진으로 수술용 가이드 제작하였다(Fig. 2C-D). 제작한 수술용 가이드에서 잠정적인 임플란트 식립 위치 에 access hole을 뚫고 방사성 불투과성 지표(Gutter percha)로 충전하였다. 수술용 가이드 장착 후 콘빔 전산화
단층(Cone beam computed tomography, CBCT) 촬영 진행하였으며 OnDemand 3D ${ }^{\mathrm{TM}}$ (Cybermed Inc., Seoul, Korea) 소프트웨어를 통해 최종적인 임플란트 식립 위치 와 개수를 결정하였다. 이에 따라 상악은 전치부 협측 골 증대술 동반한 9개 임플란트(좌측 중절치, 양측 견치, 양 측 제 1 소구치, 양측 제 2 대구치, 우측 제 1 대구치, 좌측 제 2소구치), 하악은 양측 견치부 협측 골 증대술 동반한 8 개의 임플란트(양측 견치, 양측 제 1 소구치, 양측 제 1,2 대 구치) 식립하기로 구체화하였다(Fig. 3).

임플란트 식립은 앞서 $\mathrm{CBCT}$ 촬영 시 장착한 수술용 가이드를 이용하여 발치 6 개월 후부터 상악 구치부, 하 악, 상악 전치부 순서로 총 3 회에 나누어 진행하였다. 상 악 구치부의 경우 우측 제 1 소구치 협측 골 이식술 동반 하여 소구치부는 3 개의 직경 $4 \mathrm{~mm}$ 외부 육각 연결 임플 란트(USII SA Regular, Osstem, Seoul, Korea), 구치부 는 3 개의 직경 $5 \mathrm{~mm}$ 외부 육각 연결 임플란트(USII SA Wide, Osstem) 식립 후 치유지대주 체결하였다(Fig. 4A). 하악의 경우 양측 견치와 제 1 소구치 부위에 조직유도골 재생술 (Guided Bone Regeneration, GBR) 동반한 4개 의 직경 $4 \mathrm{~mm}$ 외부 육각 연결 임플란트 구치부는 4 개 의 직경 $5 \mathrm{~mm}$ 외부 육각 연결 임플란트 식립 후 치유지 대주 체결하였다(Fig. 4B). 상악 전치부의 경우 양측 견 치 및 좌측 중절치에 GBR 동반한 3개의 직경 $4 \mathrm{~mm}$ 외 부 육각 연결 임플란트 식립 후 치유지대주 체결하였다.
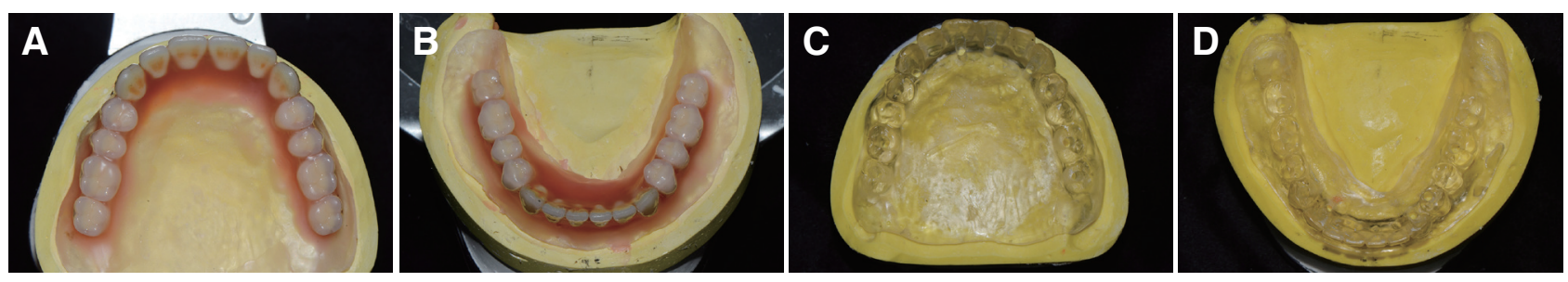

Fig. 2. Implant surgical stent fabrication artificial tooth arrangement (A - B), implant surgical stent (C-D). (A) Artificial tooth arrangement (maxilla), (B) Artificial tooth arrangement (mandible), (C) Implant surgical stent (maxilla), (D) Implant surgical stent (mandible).

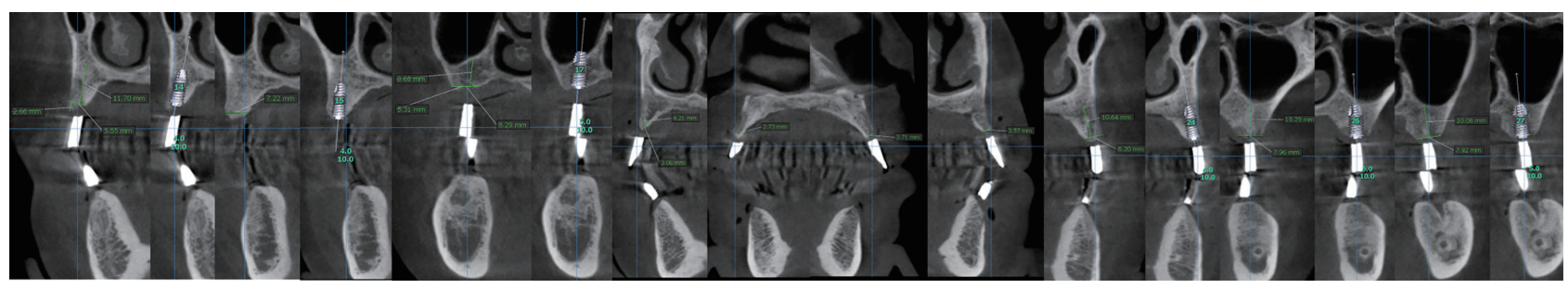

Fig. 3. Implant surgical Planning with OnDemand 3D ${ }^{\mathrm{TM}}$. 

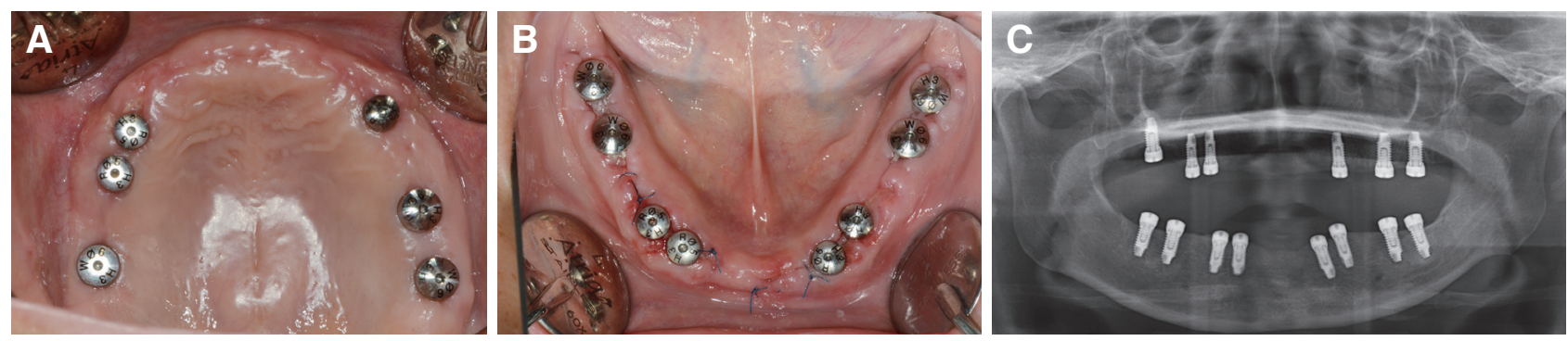

Fig. 4. After implant installation intra oral photos (A-B), radiographic evaluation (C). (A) Anterior area buccal bone was augmented, (B) Healing abutments were connected after installation, (C) Panorama radiograph after fixture installation.
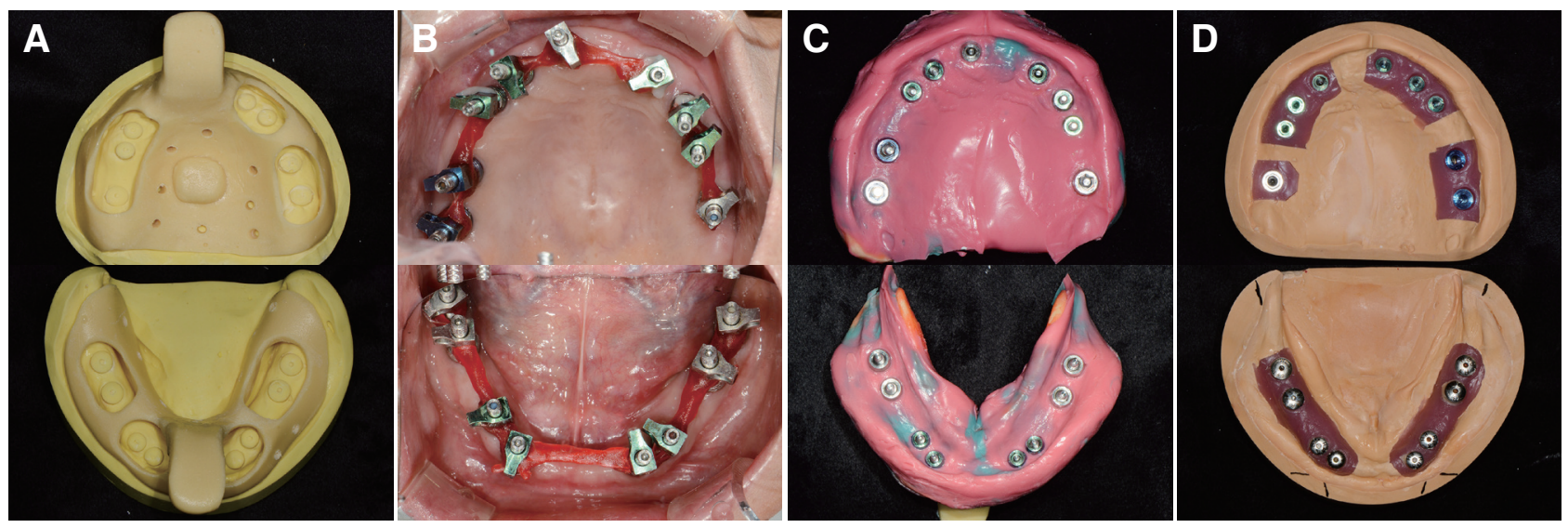

Fig. 5. Fixture level impression (A-D). (A) Individual trays were fabricated, (B) Copings were splinted in the oral, (C) Fixture level impressions were taken, (D) Master casts were fabricated with gum replica.

조직유도골재생술은 이종골(Bio-Oss, Geistlich Pharma $\mathrm{AG}$, Wolhusen, Switzerland)과 흡수성 콜라겐 막(OSSIX Plus ${ }^{\circledR}$, Dentsply Sirona, York, USA) 이용하여 진행하였 다. 치유 지대주에 맞게 상, 하악 임시 총의치 첨상 진행 하였다.

상악 전치부 임플란트 식립 2주 후 임플란트 안정성 지 수(Implant stability quotient, ISQ)를 OSSTELL (Osstell $\mathrm{AB}$, Goteborg, Sweden) 이용하여 측정한 결과 모든 식 립 위치에서 78-90 사이의 수치 나타내어 임시 수복 물 제작 진행하였다. 예비 인상 채득 후 폴리 메틸 메타 크릴레이트(SR Ivolen ${ }^{\circledR}$, Ivoclar Vivadent AG, Schaan, Liechtenstein) 이용하여 맞춤 트레이 제작하였다(Fig. $5 \mathrm{~A})$. 구강내에서 임플란트 인상용 코핑(US fixture pickup impression coping, Osstem)을 식립 위치에 맞게 장 착한 후 아크릴 레진(Pattern Resin LS, GC Corporation, Tokyo, Japan)로 연결 고정하고 폴리이써 인상재 $\left(3 \mathrm{M}^{\mathrm{TM}}\right.$ $\mathrm{IMPREGUM}^{\mathrm{TM}}, 3 \mathrm{M}$, St. Paul, USA) 이용하여 픽업 인상 채득 진행하였다(Fig. 5B-C).
기록상과 교합제로 수직 고경과 구순 지지 결정하여 중심위에서 교합 채득 진행한 후 반조절성 교합기(PRO$\mathrm{TARevo}^{\mathrm{TM}} 5, \mathrm{KaVo}$, Brea, USA)에 모형 부착하였다 (Fig. 6A-C). 상, 하악 모형에 임시 지대주(US Temporary Abutment, Osstem) 장착 후 진단 왁스업 시행하여 나사 유지형 임시 수복물 제작하여 환자의 구강 내에 장착하 였다(Fig. 7A-E). 상 하악 양측 견치유도 교합 형성하여 측방 운동 시 구치부 임플란트에 과도한 하중이 가해지 는 것을 방지하였으며 전치부 균일한 전방 유도 설정하 였다.

한 달 동안의 추적 관찰 후 ‘전치부가 꺼져 보이고 안모 가 짧아 보인다'는 환자의 심미적 요구 반영하여 구순 지 지와 수직 고경을 1-2 mm 증가시킨 2번째 고정성 임시 수복물 장착 진행하였다. 2 번째 임시 수복물은 첫 번째 임시 수복물에서 상악 전치부를 $2 \mathrm{~mm}$ 전방 이동시켜 구 순 지지를 증대시키고, 교합기 전치 유도 핀을 $1 \mathrm{~mm}$ 거 상하여 수직 고경을 증가시켜 제작하였다. 2회의 상, 하 악 전치부 길이 수정, 치경부 레진 첨상 및 수평 피개 증 

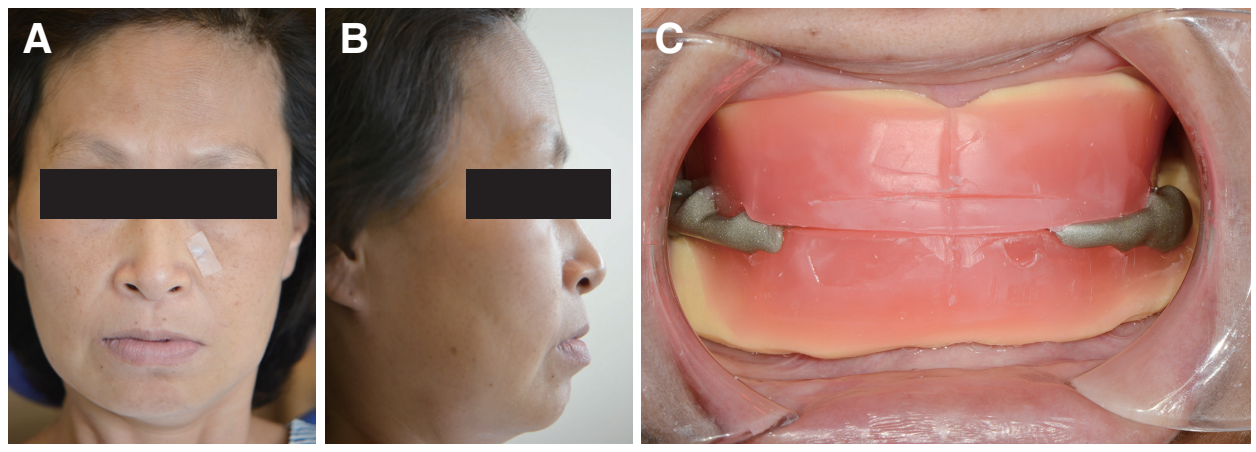

Fig. 6. Bite registration with Recording bases (A-C), (A) Decision of vertical dimension, (B) Decision of lip support, (C) Bite registration with Alu wax.
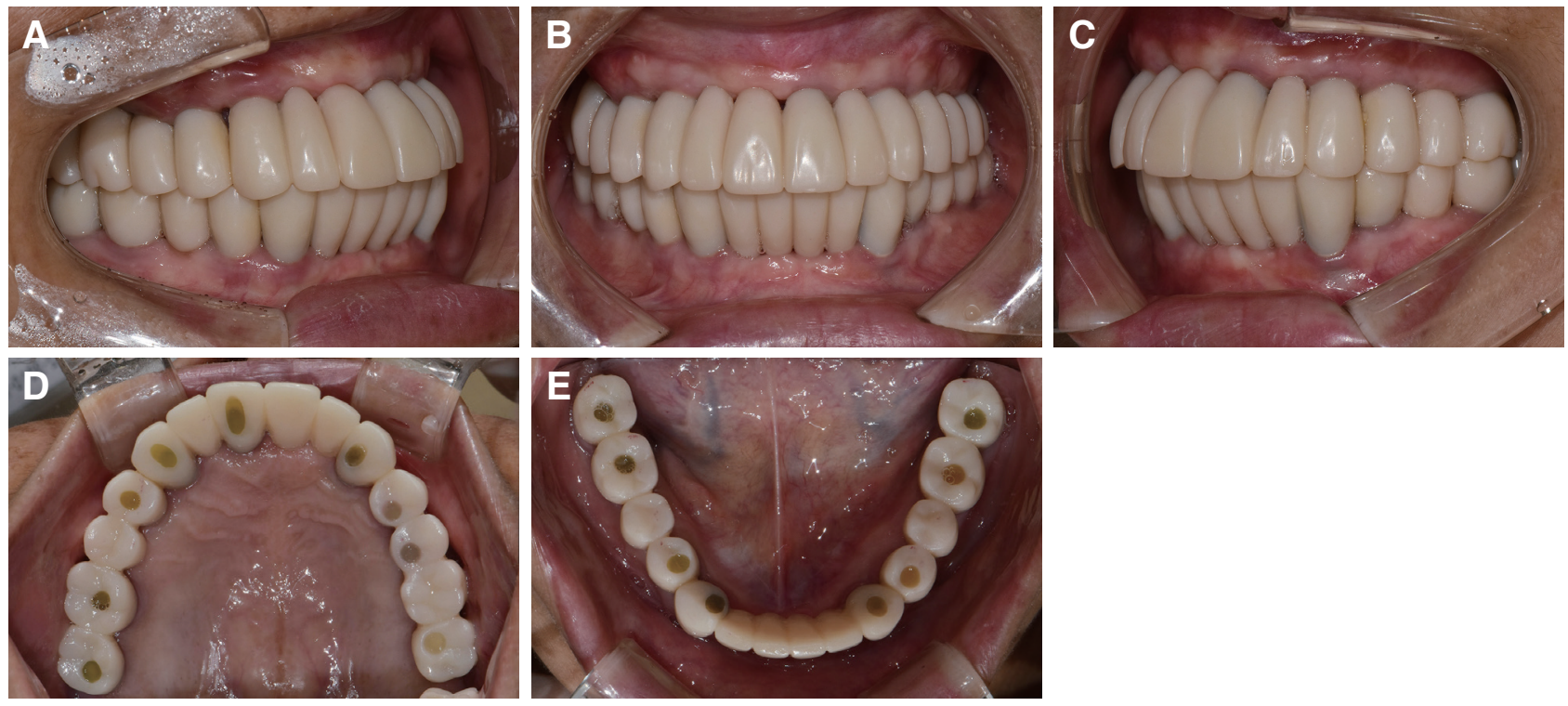

Fig. 7. Provisional prosthesis (screw type). (A) Lateral view (right side), (B) Frontal view, (C) Lateral view (left side), (D) Occlusal view of maxilla, (E) Occlusal view of mandible.

가시켜 임시 수복물 추가 수정 진행한 후 환자가 임시 수 복물에 심미적 기능적으로 만족하였으며 ISQ 값이 임시 치아 장착 후 $80-90$ 사이로 안정적으로 유지되었고 이 후 기능, 심미, 발음, 위생 등의 최종 보철물을 제작하는 데 중요한 변수를 6 개월의 기간 동안 평가하였다. 이 기 간 동안 환자의 위생관리 능력 및 보철물에 대한 만족도 등을 평가할 수 있었다. ${ }^{3}$ 환자가 심미적, 기능적 측면에서 임시 수복물에 만족하여 이를 반영한 최종 수복물 제작 진행하기로 결정하였다.

최종 수복은 상악 구치부, 하악 구치부, 상, 하악 전치 부 순으로 3 회에 나누어 진행하기로 하였다. 상악 구치 부 인상 채득을 위해 폴리 메틸 메타크릴레이트 이용하 여 맞춤 트레이 제작하여 인상용 코핑을 식립 위치에 맞
게 장착한 후 폴리이써 인상재 이용하여 픽업 인상 채득 진행하였다(Fig. 8A-D).

모형상에 임시지대주 장착 후 광중합 레진(Lightplast Basisplatten, Dreve, Max-Planck, Germany)으로 제작한 바이트 블록을 이용하여 교합관계 채득 진행하였다. 상, 하악 임시 수복물 장착 상태의 알지네이트 인상 채득 진 행하여 교차 마운팅(cross-mounting)을 시행하였다. 이 렇게 부착된 상, 하악 모형상에서 나사 유지형 금속 도재 관으로 최종 수복물 제작하여 환자에게 장착하였다. 같 은 방법으로 하악 구치부 나사 유지형 금속도재관 최종 수복물 장착하였으며 이후 상, 하악 전치부는 티타늄 맞 춤 지대주 이용한 나사 시멘트 유지형 보철물(screw cement retained prosthesis)로 수복하기로 결정하였다. 상, 

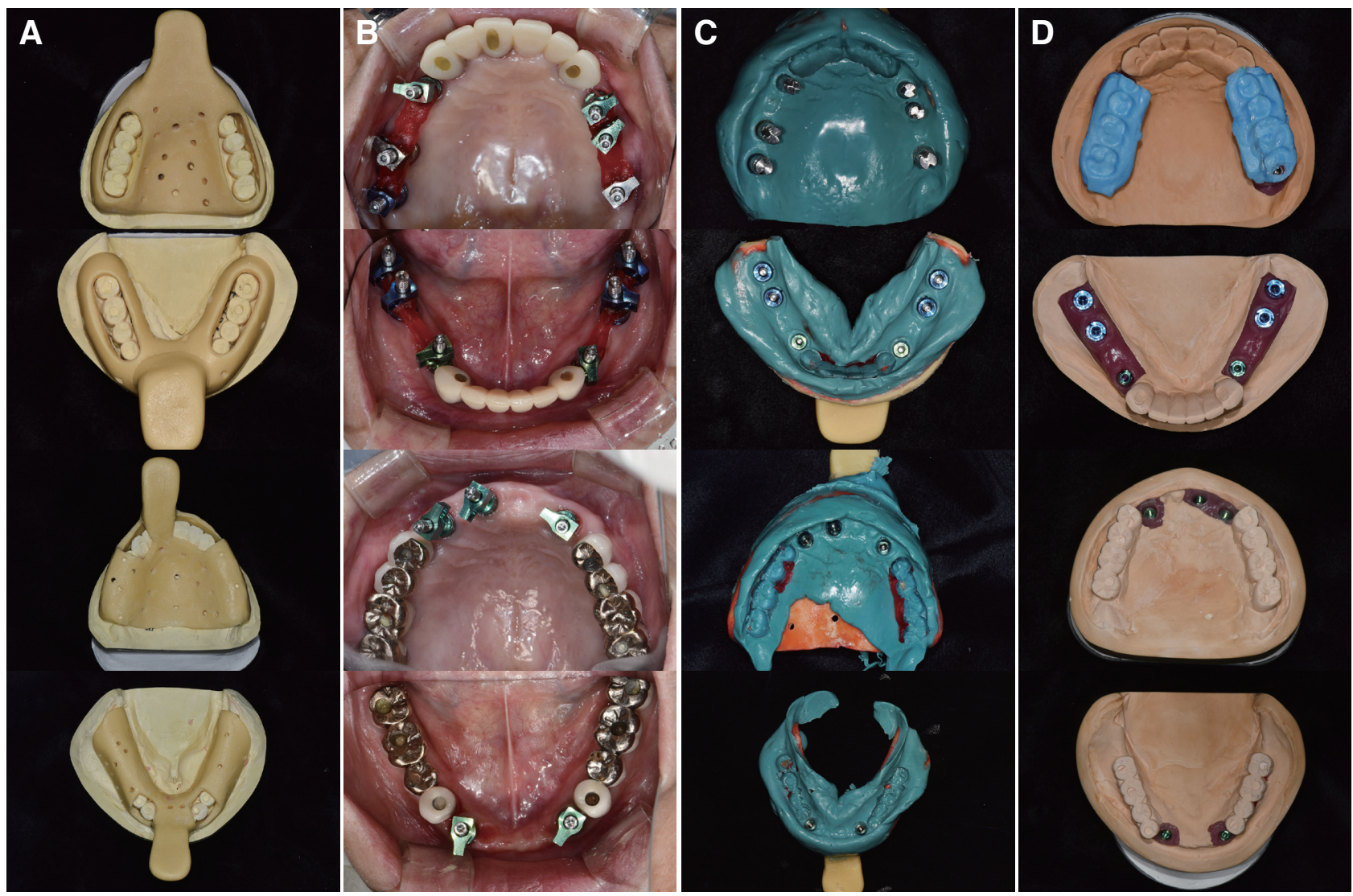

Fig. 8. Fixture level impression (A-D). (A) Individual trays were fabricated, (B) Copings were connected in the oral, (C) Fixture level impressions were taken, (D) Master casts were fabricated with gum replica.

하악 전치부의 경우 인상 채득 후 티타늄 맞춤 지대주 및 금속 코핑 제작하여 교합채득 진행 후 최종 보철물 제작 하였다. 상, 하악 전치부 최종 수복물은 이중 중합형 레진 시멘트 $\left(\operatorname{RelyX}^{\mathrm{TM}} \mathrm{U} 200,3 \mathrm{M}\right)$ 이용하여 접착하였고 보철 물은 제조사 지시에 따라 $30 \mathrm{Ncm}$ 으로 조였다. 최대 교 두 감합위에서 양측 구치부가 균일하게 접촉되도록 교합 설정해 주었으며 측방 운동 시 양측 견치유도 교합 형성 하였다. 전방 운동 시에는 균일한 전방유도가 이루어지 도록 하였다. 갑상선 중독증 관련 치주염 발병 위험성 고 려하여 최종 보철물에서 치간 공극을 위생 관리에 양호 한 형태로 제작하였다. 최종 수복 후 환자는 구순 지지, 저작 및 발음에 만족하였으며 전체적인 교합 양상은 안 정적으로 유지되었다. 또한, 환자의 구강 위생 상태는 양 호하였고 임플란트 식립 부위 치조골 수준도 최종 수복 전과 비교 시 안정적으로 유지되었으며 환자와 술자는 심미적 기능적 결과에 대해 만족하였다(Fig. 9A-H). 취침 시 나이트 가드를 착용하도록 교육하였으며 이후 환자 는 갑상선 중독증에 의한 치주질환 발병 위험도 고려하
여 3개월 간격으로 내원하여 구강 위생 관리를 시행하고 있다. 6 개월의 기간 동안 도재 파절 등의 보철적 합병증 없이 안정적인 기능적, 심미적 예후를 확인할 수 있었다.

환자의 갑상선 중독증에 의한 구강건조증으로 타액의 작용이 감소하여 치태 및 치석 침착 위험도가 증가할 것 을 고려하여 치간 칫솔, 치실 사용 및 잇솔질 방법 교육하 였으며 향 후 3개월 간격으로 주기적으로 내원하도록 지 시하여 구강위생 관리를 시행할 예정이다. 또한 재내원 시 보철물의 하악전치부 설측면 및 치간 공극 등 구강위 생 관리가 어려운 부분을 집중적으로 평가 및 검사해야 할 것이다.

\section{고찰}

갑상선 중독증 환자의 경우 심장 기능 이상이 동반되 는 경우가 많기 때문에 이로 인한 치과적 합병증을 줄이 기 위해서는 치과 치료 시 주의를 기울여야 한다. ${ }^{2}$ 환자가 갑상선 중독증을 않고 있다면 치과 치료 전 심혈관계 합 

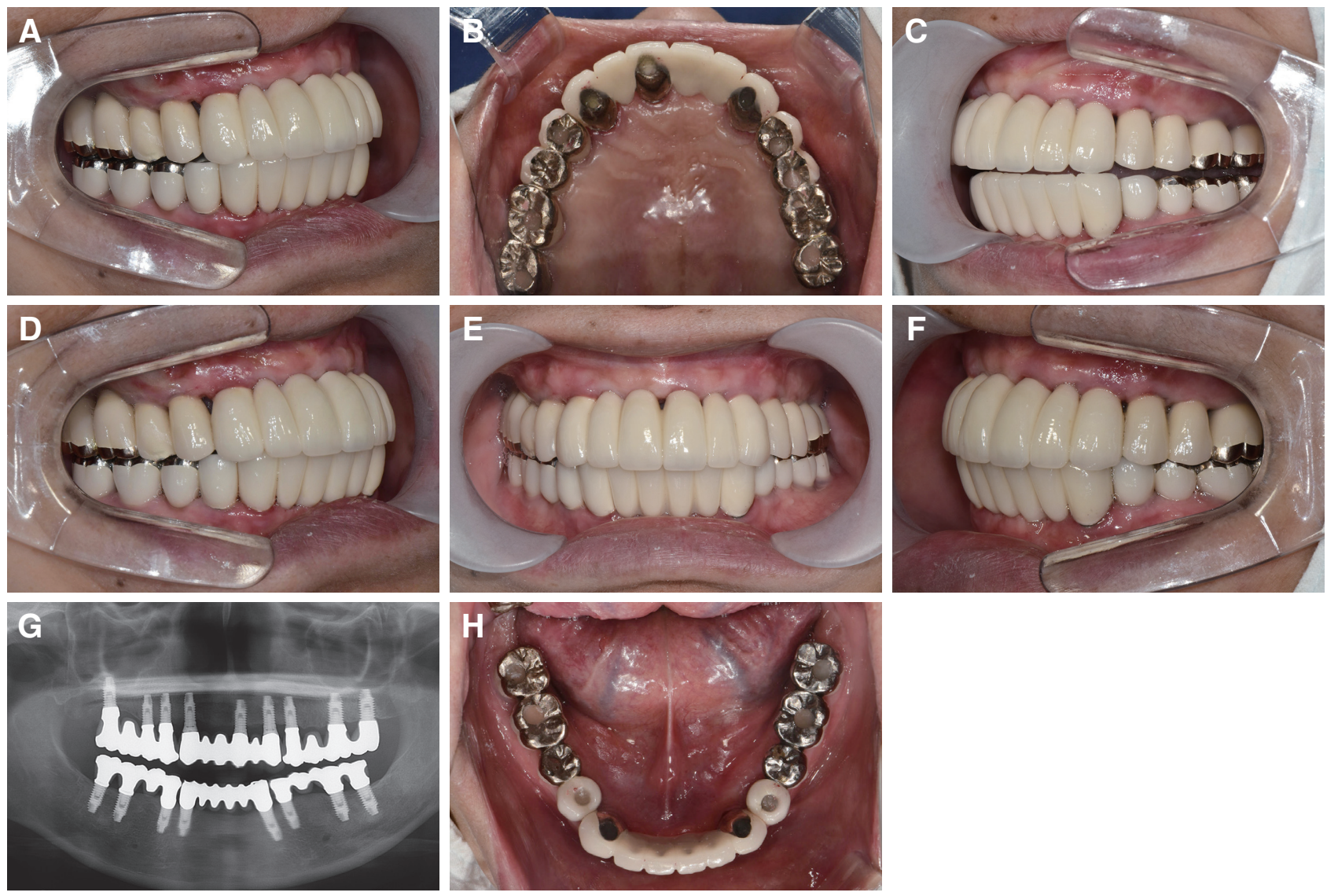

Fig. 9. Post-operative intraoral photograph $(A-F, H)$, radiographic evaluation $(G)$. (A) Canine guidance at right side, $(B)$ Maxillary occlusal view, (C) Canine guidance at left side, (D) Right lateral view, (E) Frontal view, (F) Left lateral view, (G) Panoramic radiograph, (H) Mandibular occlusal view.

병증을 가지고 있는지, 이와 관련하여 항응고 약물을 복 용하고 있는지 확인해 보아야 할 것이다. 만일 환자가 해 당 약물을 복용하고 있다면 치과 치료 전 위 약물의 중단 및 조절에 대해 내과 전문의와 상의해야 할 것이다. ${ }^{2}$ 치 과 시술 중에 환자에게 가급적 스트레스를 유발하지 않 도록 해야 한다. ${ }^{2}$ 만약 치과 치료 도중 발열, 섬망 등의 갑 상선 중독증 위기 증상이 나타났다면 즉각적으로 치료를 중단해야 한다. ${ }^{2}$ 또한 에피네프린은 a-아드레날린 수용 체에서는 혈관 수축 작용을 나타내고 b-아드레날린 수용 체에서는 혈관 확장 작용을 나타내는데 환자가 갑상선 중독증 관련하여 b- 차단제를 복용하고 있다면 에피네프 린 사용 시 a- 아드레날린 수용체에 대한 작용이 강화되 어 혈압 증가 등이 유발될 수 있으므로 치과 시술 시 에 피네프린 사용을 최소로 해야 할 것이다. ${ }^{4}$ 문헌에 따르면 잘 조절되는 갑상선 중독증의 경우 치과치료의 특별한 금기증이 되지 않는 것으로 보고되었다. ${ }^{2}$ 치과 치료가 끝 난 후에는 통증 조절에 주의를 해야 하며 비스테로이드
성 진통제의 경우 $\mathrm{b}$-차단제의 효과를 약화시킬 수 있으 므로 해당 약물을 복용 중인 환자라면 다른 약물로 대체 하거나 최소한으로 처방해야 할 것이다. ${ }^{2}$ 본 증례의 환자 는 잘 조절되는 갑상선 중독증 환자로 내과 의사와 상의 하여 아스피린, 기넥신 등 출혈 가능성을 증가시키는 약 물을 시술 전 7일간 중단하고 에피네프린 최소 사용하여 발치 및 임플란트 식립 진행하였다. 또한 술 후 통증 조절 을 위해 아세트아미노펜을 처방하여 비스테로이드성 진 통제를 대체하였다.

심한 치조골 소실, 전치부 구순 지지 상실 등 임상적으 로 조건이 좋지 않은 환자를 임플란트 지지 고정성 수복 물로 심미적, 기능적으로 만족스럽게 수복하는 데에는 많은 어려움이 따른다. ${ }^{1}$ 구순지지는 잔존 치조제의 형태 와 전치부 보철물의 치경부 윤곽에 의해 결정된다. ${ }^{1}$ 전치 부 보철물의 치체를 전방으로 이동시키는 것과 치경부 윤곽을 풍융하게 형성하는 것을 통해 감소된 구순 지지 를 어느 정도 회복할 수 있겠으나 진단 왁스업 모형에서 
전치의 이상적 위치와 잔존 치조제 사이의 불일치가 크다 면 적절한 구순 지지는 가철성 보철물의 협측 변연에 의 해서만 확립될 수 있을 것이다. ${ }^{1}$

임플란트 지지 고정성 보철물로 결손치의 치관을 수복 할 때 지르코니아와 금속 도재관 2가지 재료를 현재 가 장 보편적으로 이용하고 있다. 이러한 도재 수복물의 대 표적인 합병증에는 도재 파절이 존재하는데 여러 문헌 에서 단일 치아 수복시에는 지르코니아와 금속도재관에 서 도재 파절, 나사의 파절, 보철물의 유지력 상실이 일어 나는 빈도가 통계적으로 유의한 차이를 나타내지 않은 것으로 보고하였다. ${ }^{5-11}$ 하지만 $\mathrm{Hu}$ 등은 다수 치아를 수 복하는 임플란트 지지 고정성 수복물에서는 지르코니아 의 성공률이 금속 도재관의 성공률에 비해 낮다고 보고 하였다. 또한 Shi 등은 지르코니아의 경우 금속 도재관 에 비해 유지 관찰 기간 동안 연마를 요구하는 도재 파절 이 통계적으로 유의하게 잦은 빈도로 일어났으며, 이로 인해 금속 도재관과 비교 시 연마와 같은 유지 보수가 빈 번하게 이루어져야 함이 보고한 바 있다. ${ }^{7}$ 최근에는 도재 파절에 대한 대안으로 단일구조 지르코니아(monolithic zirconia)를 통한 전악 고정성 수복이 이루어지고 있다. ${ }^{5}$ 모노리식 지르코니아는 단일 구조적 특성으로 인해 개선 된 마모 저항성, 높은 심미성 및 더 적은 바이오 필름 형 성 등의 장점을 가지며 캐드캠(computer-aided-design computer-aided-manufacturing)제작 기법을 이용한 보 철물 수리 및 재제작에서의 이점이 있다. ${ }^{5}$ 또한 Weigl 등 은 금속 도재관과 비교 시 단일 구치부 수복시에 도재 파 절 빈도가 낮았으며 연조직 반응은 통계적으로 유의한 차이가 나타나지 않았다고 보고하였다. ${ }^{12}$ 하지만 금속도 재관과 비교 시 단일구조 지르코니아를 이용한 전악 고 정성 수복에 대한 장기적인 예후에 대한 연구가 부족하 므로 재료 선택에 있어서 신중을 기해야할 것이다. ${ }^{5}$ 본 증 례 환자의 경우 최종 수복 시 다수 치관의 연결 고정된 형 태의 보철물을 제작할 것이므로 파절의 우려가 적어 합 병증의 빈도가 낮고 유지 보수의 필요성이 적은 금속 교 합면의 금속 도재관을 최종 수복 재료로 선택하였다. 결 과적으로 환자는 유지 관찰 기간 동안 도재 파절 등의 보 철 실패를 보이지 않았다.

임플란트 고정성 보철물은 크게 나사 유지형과 시멘트 유지형으로 분류될 수 있다. 문헌에 따르면 임플란트 단 일관의 경우 나사 풀림, 금속 구조물 파절 등의 기계적 합 병증은 스크류 유지형에서 통계적으로 유의하게 높은 빈 도로 나타났다. ${ }^{11}$ 하지만 Christopher 등은 수복하는 치
관수가 많아질수록 특히 임플란트 전악 고정성 수복에서 는 생물학적 합병증과 기계적 합병증 모두 시멘트 유지 형에서 통계적으로 유의하게 높은 빈도로 일어난 것으로 보고하였다. ${ }^{13}$ 더불어 나사 유지형 및 나사 시멘트 유지형 보철물의 경우 이러한 합병증이 일어나더라도 나사 구멍 을 통해 술자가 보철물을 용이하게 탈착할 수 있어 합병 증에 더욱 용이하게 대처할 수 있을 것이다. 이에 따라 본 증례에서는 임플란트 전악 고정성 수복 시 합병증의 빈 도, 합병증 발생 시 대처의 용이성 등을 고려하여 구치부 나사 유지형, 전치부 나사 시멘트 유지형 보철물로 수복 하여 향후 합병증 발생 시 보철물을 탈착하여 용이하게 합병증에 대처할 수 있을 것이다.

\section{결론}

본 증례에서는 발치와 임플란트 식립을 각각 3 회에 걸 쳐 진행하였으며 임플란트 식립 시 구순 지지와 수직 고 경을 반영하여 제작한 수술용 가이드를 이용해 정확한 위치에 고정체를 식립할 수 있었다. 환자와 술자 모두 심 미적 기능적으로 만족할 만한 결과를 얻을 수 있도록 임 시 수복물을 장착한 후 환자와의 소통을 통해 이를 평가 및 수정하였다. 최종 수복은 상악 구치부, 하악 구치부, 상, 하악 전치부 3 회에 나누어 진행하였으며 결과적으로 환자는 최종 수복 완료 후 구순 지지, 저작 및 발음 등 심 미적 기능적으로 크게 개선된 예후를 보였다.

\section{ORCID}

Hee-Hyun Shin https://orcid.org/0000-0003-3923-1327

Jong-Jin Kim https://orcid.org/0000-0003-1815-3294

Jin Baik https://orcid.org/0000-0002-3622-3113

Hyun-Suk Cha https://orcid.org/0000-0001-5164-5181

Joo-Hee Lee https://orcid.org/0000-0001-5644-0126

\section{References}

1. Jivraj S, Chee W, Corrado P. Treatment planning of the edentulous maxilla. Br Dent J 2006;201;261-79.

2. Chandna S, Bathla M. Oral manifestations of thyroid disorders and its management. Indian J Endocrinol Metab 2011;15;113-6.

3. Picha S, Gollner M. Implantoprothtische Ver- 
sogrung im zahnlosen Ober- Und Uterkiefer Konsequent strukturiertes und teamorientietes Vorgehen. Quintessence Dent Technol 2019;21:34-45.

4. Pinto A, Glick M. Management of patients with thyroid disease: oral health considerations. J Am Dent Assoc 2002;133:849-58.

5. Abdulmajeed AA, Lim KG, Närhi TO, Cooper LF. Complete-arch implant-supported monolithic zirconia fixed dental prostheses: A systematic review. J Prosthet Dent 2016;115:672-7.

6. Hu ML, Lin H, Zhang YD, Han JM. Comparison of technical, biological, and esthetic parameters of ceramic and metal-ceramic implant-supported fixed dental prostheses: A systematic review and metaanalysis. J Prosthet Dent 2020;124:26-35.

7. Shi JY, Zhang XM, Qiao SC, Qian SJ, Mo JJ, Lai HC. Hardware complications and failure of threeunit zirconia-based and porcelain-fused-metal implant supported fixed dental prostheses: a retrospective cohort study with up to 8 years. Clin Oral Implants Res 2017;28:571-5.

8. Jung RE, Holderegger C, Sailer I, Khraisat A, Suter A, Hämmerle CHF. The effect of all-ceramic and porcelain-fused-to-metal restorations on marginal peri-implant soft tissue color: a randomized controlled clinical trial. Int J Periodontics Restorative Dent 2008;28:357-65.

9. Gallucci GO, Grütter L, Nedir R, Bischof M, Belser UC. Esthetic outcomes with porcelain-fusedto-ceramic and all-ceramic single-implant crowns: a randomized clinical trial. Clin Oral Implants Res 2011;22:62-9.

10. Morton D, Gallucci G, Lin WS, Pjetursson B, Polido W, Roehling S, Sailer I, Aghaloo T, Albera H, Bohner L, Braut V, Buser D, Chen S, Dawson A, Eckert S, Gahlert M, Hamilton A, Jaffin R, Jarry C, Karayazgan B, Laine J, Martin W, Rahman L, Schlegel A, Shiota M, Stilwell C, Vorster C, Zembic A, Zhou W. Group 2 ITI Consensus Report: Prosthodontics and implant dentistry. Clin Oral Implants Res 2018;29:215-23.

11. Wittneben JG, Buser D, Salvi GE, Bürgin W, Hicklin S, Brägger U. Complication and failure rates with implant-supported fixed dental prostheses and single crowns: a 10-year retrospective study. Clin
Implant Dent Relat Res 2014;16:356-64.

12. Weigl P, Saarepera K, Hinrikus K, Wu K, Trimpou G, Lorenz J. Screw-retained monolithic zirconia vs. cemented porcelain-fused-to-metal implant crowns: a prospective randomized clinical trial in splitmouth design. Clin Oral Investig 2019;23;1067-75.

13. Millen C, Brägger U, Wittneben JG. Influence of Prosthesis Type and Retention Mechanism on Complications with Fixed Implant-Supported Prostheses: A systematic Review Applying Multivariate Analyses. Int J Oral Maxillofac Implants 2015;30:110-24. 


\title{
고정성 임플란트 보철물을 이용한 완전 무치악 환자의 구강회복 증례
}

\author{
신희현 ${ }^{1}$ 전공의, 김종진 ${ }^{1}$ 교수, 백 진 $^{1}$ 교수, 차현석 ${ }^{2}$ 교수, 이주희 ${ }^{2 *}$ 교수 \\ ${ }^{1}$ 서울아산병원 치과 보철과 \\ ${ }^{2}$ 서울아산병원 치과 보철과, 울산대학교 의과대학
}

완전 무치악 환자의 구강 회복은 통상적 총의치, 하이브리드 보철물, 임플란트 지지 고정성 보철물 등 다양한 치료 옵션 을 통해 이루어질 수 있다. 전악 임플란트 고정성 보철 수복의 경우 가철성 수복과 비교해 최종적인 보철물의 형태를 고 려하여 정확한 위치에 임플란트를 식립해야 한다는 어려움이 따른다. 본 증례에서는 치아우식과 만성 치주염으로 전악 발거를 요하는 환자의 전악 임플란트 고정성 수복을 진행하였다. 임플란트 식립 단계에서 최종 보철물 형태를 고려하여 제작된 수술용 가이드를 이용하여 원하는 위치에 임플란트를 식립 하였으며 고정성 임시 수복물 단계에서 수정 및 재제 작을 통해 기능과 심미를 평가하였다. 이렇게 제작된 임시 수복물을 바탕으로 금속 도재관의 최종 수복물을 장착하였다. 나사 풀림 및 도재 파절 등의 합병증에 대처하기 위해 구치부의 경우 나사 유지형 보철물, 전치부는 나사 시멘트 유지형 보철물로 제작하였다. 그 결과 환자는 최종 보철물 장착 후 기능적 심미적 측면에서 개선된 예후를 보였다.

(구강회복응용과학지 2021;37(3):147-56)

주요어: 완전무치악; 임플란트 고정성 보철 수복; 임플란트 수술용 가이드

*교신저자: 이주희

(05505) 서울특별시 송파구 올림픽로 43길 88 서울아산병원 치과 보철과

Tel: 02-3010-3850 | Fax: 02-3010-6967 | E-mail: ljhl11911@hanmail.net

|접수일: 2021년 7월 23일 | 수정일: 2021년 8월 3일 | 채택일: 2021년 8월 25일 